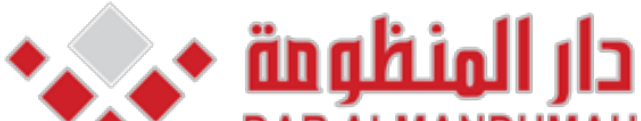 DAR ALMANDUMAH

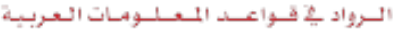

The Relationship Between Test Anxiety And Saudi

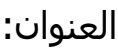
Students Achievement In English

$$
\text { دراسات تربوية ونفسية }
$$

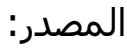

جامعة الزقازيق - كلية التربية

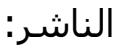

Al-Subahi, Abdulhai

المؤلف الرئيسي:

$98 \varepsilon$

المجلد/العدد: - المولفيس

نعم

محكمة:

التاريخ الميلادي: 2018

يناير

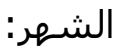

$333-363$

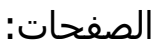

884390

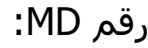

بحوث ومقالات

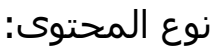

English

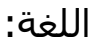

قواعد المعلومات: EduSearch

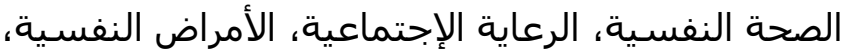

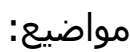

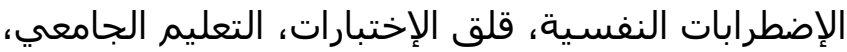

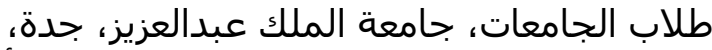

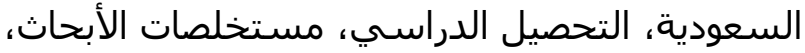
اللغة الإنجليزية

http://search.mandumah.com/Record/884390 


\title{
The Relationship between test Anxiety and Saudi Student's Achievement in English
}

\author{
Prof. AbdulHai AL-Subahi \\ Dept. Curriculum and Instruction \\ King Abdulaziz University
}

الملنخص

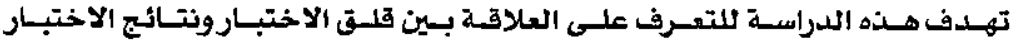

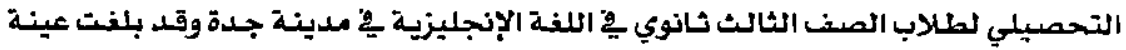

$$
\begin{aligned}
& \text { البحث سبعمائة وثلاثة طلاب من مداربس جدة الثانوية بينما كانت أداتي البحث هما مقيساس }
\end{aligned}
$$

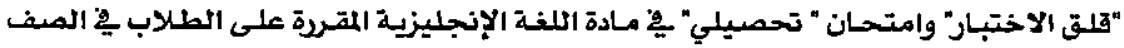

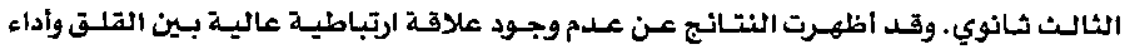

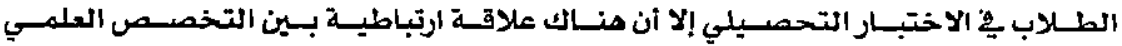

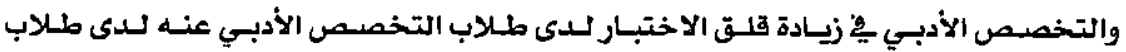

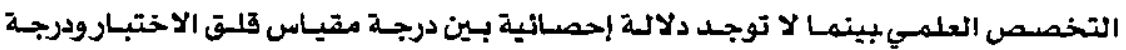

$$
\begin{aligned}
& \text { الاختبار التحصيلي بالنسبة مناطق الإشراف التربوي يِّ جدة. }
\end{aligned}
$$

\section{Abstract}

The purpose of this study is to identify the relationship between test-anxiety and the students achievement test in English at the third grade secondary school in Jeddah. The sample study is seven hundred and three students. The instruments used are an anxiety-test scale and achievement test. The findings show that there is no significant correlation between the anxiety-test and the students' performance at the achievements English test. The resuits of the anxiety test scale show that Literary major students are more anxious about the English test than scientific major students. However, there is no statistical significant correlation among the target students concerning the educational supervision centres.

\section{Introduction}

Tests in Saudi schools have always been used as the main criteria for judging student's scientific abilities, school achievements and a means of career consent. On surveying English teachers' opinions at secondary schools, about test 
anxiety, it is found that most of the secondary graders show $\therefore$ and verbalize a great deal of anxiety regarding English tests, which affect their achievement. Mc Donald (2001) says that between two thirds of high school students appear to experience uncomfortable levels of test anxiety. Masson, Hoyois,Pcadot, Nahma, Petit and Ansseau (2004) have found that high school students with high test anxiety have a poor school performance. Test anxiety is a multidimensional signs that can be described as a group of phenomenological, physiological and behavioral reactions to appear with possible negative consequences or failure on an examination as similar evaluative situation. (Zeidner, 1998). Test anxiety has an impact on academic performance and working memory (Eysneck, 2001), Sarason (1984), as cited in ' Keoghi', Bond, French, Richards and Davis :(2004) has found that test anxiety decreases attention span, memory and concentration, and leads to low instructional performance. Further, test anxiety links to memory and can have an effect on educational achievement, because it disrupts attention and concentration. When attention and concentration are impaired, this will disrupt memory and as a consequence lead to low academic achievement. (Chen, Li, 2000; and Sanders, 2001 - cited in Needleham, 2006).

Anxiety has been regarded as one of the most important and effective factor that influencesforeign language learning. One the same other hand studies, e.g. Baily (1983), Harwitz\&Cope' (1986): Mclntyre\&Gardner' (1994)' Young' (1991) found out that there is no relationship between test anxiety and achievement of foreign languages. Study problem

Based on the results of the first semester 2015/2016 English test, third grade secondary students experience low level of achievement despite that they have been studying English for eight years. This unsatisfactory performance 
might be referred to test-anxiety which is assumed to affect negativelythe student's performance in English test.

\section{Purposes of the Study}

1 - Finding out the relationship between test anxiety and $3^{\text {rd }}$. grade secondary school students' achievement in English.

2- Finding out the relationship between test anxiety and $3^{\text {rd }}$. grade secondary school students' achievement in English with reference to majors ; scientific / literary.

3- Finding out the relationship between test anxiety and $3^{\text {rd }}$. grade secondary school students achievement in English with reference to the educational supervisioncentres.

\section{Study Inquires}

1- Is there a statistical significant correlation between the total scores of the English test and the scores of the anxiety test scale?.

2- Is there any statistical significant difference between means of English - test and means of anxiety - test scale with reference to majors : scientific or literary?

3- Is there any statistical significant difference between means of English test and means of anxiety test scale due to the educational supervision centers?

\section{Significance of the Study}

This study is significant because it attempts to detect the reason behind the low performance of the $3^{\text {rd }}$. grade secondary school students in English, despite that they have already finished studying English for eight years at general schools, public education. This unsatisfactory level of achievement is assumed to be referred to the test-anxiety the students suffer during English test administration, which may guide influential people who are involved in test construction to develop a matrix of test items that have no anxiety on students' performance. 


\section{Limitation of the study}

This study has been carried out during the second semester of $2015 / 2016$ on $3^{\text {rd }}$. grade secondary boy's school students in Jeddah.

\section{Terminology :}

Test - anxiety is find as " an apprehension that occurs when a student encounters examinations in any form and at any level' (Spielberger, 1980)

\section{Literature Review:}

One of the greatest crises of the educational system in many countries is the problem of low achievement of students instructional performance. Fouladi (2007) says that low instructional achievement has become the main focus of educational officials. He has indicated that academic achievement is the most important issues in education that many educators and psychologists have considered.'Peelo' and 'Waseham' (2002) have found that low achievement has been identified over time as problematic in terms of social and economic waste, as anti-egaliteratan and discriminory. One of the factors related to low academic achievement is test anxiety.

Thesymptoms of test anxiety can vary considerably and range from mild to severe. Some students experience only mild symptoms of test anxiety and still able to do fairly well on exams. Other students are nearly incapacitated by - their anxiety, performing dismally on tests as even experiencing Panic attacks before as during exams. Sena, Lowe 'Lee' (2007) clarify that test anxiety includes a number of different symptoms such as irrelevant thoughtawareness of badily - somatic -, sensations and tension inability to concentrate and to pay attention $(\mathrm{P}, 365)$. The - effect of test anxiety on academic performance has been thoroughly investigated by many researchers (Cassady\& Johnson, 2002; Rigagadeh\& tavakoli,2009; Win, 
1971) The study of the relationship between test anxiety and academic achievement has begun in the 1900's (Mc Donald, 2001). The comprehensive reviews by Hambree's studies (1988) have shown that test anxiety had a negative relation with student's performance. Therefore, the high - test anxious students tend to score lower than low-test anxious students. This result is supported by the findings of some studies of ' Eman\&Farooqi (2005) and 'Mc Donald' (2001) that anxiety leveis students are different according to academic subjects, nevertheless; some subjects elicit higher levels of anxiety than others. Subjects that are perceived by students to be difficult e.g.Maths,Physics, English, will trigger anxiety in the individual student and consequently interfere with his performance.Keeves (1985) indicates that girls are higher in measures of fear and that this fear is higher for quantitative studies comparatively with male,Zoller and Bencham (1990) found the anxiety of female to be higher than that of male students in science examinations.A study on the relationship between test anxiety and academic performance on ' $4000^{\prime}$ undergraduate and 1414 graduate students has shown that female students have significantly higher test anxiety than male. (Chapell, Blanding. Silverstein, Takahashi, Newman, Gubi and McCair, 2005). Another study which is conducted by 'Soffer' (2008) on elementary children in Florida USA, has indicated a small difference between male and femalestudents in test - anxiety in favour of females.

\section{Study Sample}

The sample of the study is seven hundred and three third grade secondary school students collected from four educational supervision centeres i.e. north, western south, eastern south and middle. The sample is selected from both majors 'scientific' and literary. Table (1) shows the 
distribution of the sample study with reference to the educational centeres and majors.

Table (1)

\begin{tabular}{|c|c|c|c|c|c|c|}
\hline Supervision & \multicolumn{2}{|c|}{ Scientific } & \multicolumn{2}{c|}{ Literary } & \multicolumn{2}{c|}{ Total } \\
\hline Centers & Frequencies & $\%$ & Frequencies & $\%$ & Frequencies & $\%$ \\
\hline North & 18 & 2.6 & 37 & 5.3 & 55 & 7.8 \\
\hline $\begin{array}{c}\text { Southern } \\
\text { west }\end{array}$ & 99 & 14.1 & 204 & 29.0 & 303 & 43.1 \\
\hline Middle & 32 & 4.6 & 49 & 7.0 & 81 & 11.5 \\
\hline $\begin{array}{c}\text { Southern } \\
\text { east }\end{array}$ & 111 & 15.8 & 153 & 21.8 & 264 & 37.6 \\
\hline Total & 260 & 37.0 & 443 & 63.0 & 703 & 100.0 \\
\hline
\end{tabular}

\section{Study Instrument}

An anxiety test scale in Englishlanguage is built to measure the students ' anxiety' before, during and after the English achievement test. It consists of fourty two items and validated by two specialized referees in the field of 'measurement (appendix :I). The scale items,are then, divided into four domains : anxiety-test general items(12 items), before the English test (10 items), during the English test (15 items) and after the English- test ( 5 items). (appendix : II). The scale is divided into five standards : strongly agree, agree, agree to some extent, disagree, strongly disagree (Appendix: III). The scale is translated into Arabic in order to be apprehended and more accessible to Arab students (Appendix : IV). To get the stability values of the scale, the anxiety test has been administered to an exploration sample of thirty three students using Cronbach's Alpha. Table (2) shows the number and values of items of the scale : general anxiety test, before anxiety test, during anxiety test and after anxiety test. 
Table (2)

\begin{tabular}{|l|l|l|}
\hline \multicolumn{1}{|c|}{ Scale Domains } & $\begin{array}{l}\text { No. of } \\
\text { items }\end{array}$ & $\begin{array}{c}\text { Cronbach's } \\
\text { Alpha }\end{array}$ \\
\hline 1. General anxiety - test items & 12 & 0.853 \\
\hline 2. Before anxiety - test items & 10 & 0.889 \\
\hline 3. During anxiety- test items & 15 & 0.885 \\
\hline 4. After anxiety test items & 5 & 0.897 \\
\hline 5. Total stability of the scale & 34 & 0.957 \\
\hline
\end{tabular}

The study instrument achieves high stability for the four domains of the exploration sample students according to Cronbach's Alpha correlation as they fluctuate between $(0.897-0853)$ and the total stability is (0.957). Table (3) shows the correlation validity values of the items of anxiety testdimensions after they administered to the exploration stuidy sample.

Table (3) A

\begin{tabular}{|r|r|r|r|r|r|r|}
\hline No. & $\begin{array}{c}\text { Domain } \\
\text { items } \\
(\mathbf{1})\end{array}$ & $\begin{array}{c}\text { Domain } \\
(\mathbf{1})\end{array}$ & $\begin{array}{c}\text { Total } \\
\text { Scale }\end{array}$ & $\begin{array}{c}\text { Domain } \\
\text { items } \\
(\mathbf{2})\end{array}$ & $\begin{array}{c}\text { Domain } \\
(\mathbf{2})\end{array}$ & $\begin{array}{c}\text { Total } \\
\text { Scale }\end{array}$ \\
\hline 01 & 01 & $0.582^{* *}$ & $0.515^{* *}$ & 08 & $0.535^{* *}$ & $0.535^{* *}$ \\
\hline 02 & 02 & $0.614^{* *}$ & $0.548^{* *}$ & 11 & $0.798^{* *}$ & $0.798^{* *}$ \\
\hline 03 & 04 & 0.536 & $0.492^{* *}$ & 12 & $0.882^{* *}$ & $0.883^{* *}$ \\
\hline 04 & 05 & $0.636^{* *}$ & $0.614^{* *}$ & 21 & $0.717^{* *}$ & $0.581^{* *}$ \\
\hline 05 & 09 & $0.583^{* *}$ & 0.518 & 22 & $0.727^{* *}$ & $0.646^{* *}$ \\
\hline 06 & 10 & $-0.377^{*}$ & $0.368^{*}$ & 23 & $0.720^{* *}$ & $0.584^{* *}$ \\
\hline 07 & 13 & $0.684^{* *}$ & 0.668 & 24 & $0.805^{* *}$ & $0.783^{* *}$ \\
\hline 08 & 15 & $0.619^{* *}$ & $0.637^{* *}$ & 37 & $0.691^{* *}$ & $0.721^{* *}$ \\
\hline 09 & 16 & $0.449^{* *}$ & $0.768^{* *}$ & 38 & $0.585^{* *}$ & 0.655 \\
\hline 10 & 20 & $0.543^{* *}$ & $0.534^{* *}$ & 40 & $0.604^{* *}$ & $0.644^{* *}$ \\
\hline 11 & 32 & $0.487^{* *}$ & $0.444^{* *}$ & - & & \\
\hline 12 & 35 & $0.682^{* *}$ & $0.711^{* *}$ & - & & \\
\hline 13 & & & & & & \\
\hline 14 & & & & & & \\
\hline 15 & & & & & & \\
\hline
\end{tabular}


Table (3) B

\begin{tabular}{|r|r|r|r|r|r|c|}
\hline No & $\begin{array}{c}\text { Domain } \\
\text { items (3) }\end{array}$ & $\begin{array}{c}\text { Domain } \\
(3)\end{array}$ & $\begin{array}{c}\text { Total } \\
\text { Scale }\end{array}$ & $\begin{array}{c}\text { Domain } \\
\text { items (4) }\end{array}$ & $\begin{array}{c}\text { Domain } \\
(4)\end{array}$ & $\begin{array}{c}\text { Total } \\
\text { scale }\end{array}$ \\
\hline 01 & 06 & $0.455^{* *}$ & $0.390^{*}$ & 03 & 0.905 & $0.818^{* *}$ \\
\hline 02 & 07 & $0.502^{* *}$ & $0.586^{* *}$ & 14 & 0.832 & $0.691^{* *}$ \\
\hline 03 & 17 & $0.681^{* *}$ & $0.630^{* *}$ & 18 & $0.916^{* *}$ & $0.825^{* *}$ \\
\hline 04 & 19 & $0.512^{* *}$ & $0.404^{* *}$ & 31 & $0.748^{* *}$ & $0.645^{* *}$ \\
\hline 05 & 25 & $0.664^{* *}$ & $0.668^{* *}$ & 34 & $0.811^{* *}$ & $0.771^{* *}$ \\
\hline 06 & 26 & 0.692 & $0.720^{* *}$ & & & \\
\hline 07 & 27 & $0.720^{* *}$ & $0.704^{* *}$ & & & \\
\hline 08 & 28 & $0.500^{* *}$ & $0.455^{* *}$ & & & \\
\hline 09 & 29 & $0.431^{* *}$ & $0.603^{* *}$ & & & \\
\hline 10 & 30 & $0.605^{* *}$ & $0.634^{* *}$ & & & \\
\hline 11 & 33 & $0.848^{* *}$ & $0.811^{* *}$ & & & \\
\hline 12 & 36 & $0.755^{* *}$ & $0.817^{* *}$ & & & \\
\hline 13 & 39 & $0.683^{* *}$ & $0.644^{* *}$ & & & \\
\hline 14 & 41 & $0.510^{* *}$ & $0.454^{* *}$ & & & \\
\hline 15 & 42 & $0.688^{* *}$ & $0.688^{* *}$ & & & \\
\hline
\end{tabular}

\section{Study Results}

Table (3) A\&B show that there is a statistical significant correlation between the total scores of the anxiety test scale.

This would answer the first inquires of the study that there is a statistical significant correlation between the total scores of the anxiety test scale. Table (4) shows the means values, percentage, standard deviation, domain rank, English- test and anxiety- test grades

Table (4)

\begin{tabular}{|l|c|c|c|c|c|c|}
\hline $\begin{array}{c}\text { Study } \\
\text { variahles }\end{array}$ & $\begin{array}{c}\text { Hypothetic } \\
\text { scores }\end{array}$ & Means & $\begin{array}{c}\text { Means } \\
\text { Percentage }\end{array}$ & $\begin{array}{c}\text { Standard } \\
\text { deviation }\end{array}$ & $\begin{array}{c}\text { Domain } \\
\text { rank }\end{array}$ & $\begin{array}{c}\text { English }+ \\
\text { inxiety test } \\
\text { grades }\end{array}$ \\
\hline $\begin{array}{l}\text { 1-Scores of } \\
\text { English test }\end{array}$ & 50 & 37.03 & 74.1 & 8.976 & - & Good \\
\hline $\begin{array}{l}\text { 2-General test } \\
\text { anxiety }\end{array}$ & 5 & 2.732 & 54.6 & 0.437 & 3 & Acceptable \\
\hline $\begin{array}{l}\text { 3- Pre-test } \\
\text { anxiety }\end{array}$ & 5 & 2.866 & 57.3 & 0.649 & 2 & Acceptable \\
\hline $\begin{array}{l}\text { 4-4-during- test } \\
\text { anxiety }\end{array}$ & 5 & 2.868 & 57.4 & 0.703 & 1 & acceptable \\
\hline $\begin{array}{l}\text { 5- Post-test } \\
\text { anxiety }\end{array}$ & 5 & 2.605 & 52.1 & 0.795 & 4 & acceptable \\
\hline $\begin{array}{l}\text { 6- Total test- } \\
\text { anxiety }\end{array}$ & 5 & 2.797 & 55.9 & 0.555 & - & acceptable \\
\hline
\end{tabular}


Inquiry (2) asks if there is any statistical significant difference between means of the English - test and means of the anxiety test scale with reference to either educational majors : scientific or literary. Table (5) shows the correlation between the means of the achievement English test and the means of the anxiety -test scale with reference to the secondary school two majors by using Pearson Correlation Coefficient.

\section{Table (5)}

\begin{tabular}{|c|c|c|c|}
\hline Group & \multicolumn{3}{|c|}{ The whole sample $(\mathrm{N}=703)$} \\
\hline 3-Anxiety test & Correlation - value & significant & variance \\
\hline Genera! nxiety & $* * 0.357$ & 0.01 low & 0.13 \\
\hline Pre- anxiety test & 0.312 & $0 . \overline{01}$ & $0 . \overline{10}$ \\
\hline during anxiety test & ${ }^{* *} 0.368$ & 0.01 low & 0.14 \\
\hline 7-Post- anxiety test & $* * 0.35 !$ & 0.01 low & 0.12 \\
\hline Total anxiety & 0.394 & 0.01 low & 0.16 \\
\hline Group & \multicolumn{3}{|c|}{ Scientific section $(\mathrm{N}=\mathbf{2 6 0})$} \\
\hline 3-Anxiety test & Correlation value & significant & variance \\
\hline General nxiety & ${ }^{* *} 0.186$ & 0.01 & 0.04 \\
\hline Pre- anxiety test & $* * 0.160$ & $\begin{array}{l}0.01 \\
\text { low }\end{array}$ & 0.03 \\
\hline during anxiety test & $* * 0.195$ & 0.01 low & 0.04 \\
\hline 7-Post- anxiety test & $* * 0.195$ & 0.01 low & 0.04 \\
\hline Total anxiety & $* * 0.211$ & $\begin{array}{l}0.01 \\
\text { low }\end{array}$ & 0.05 \\
\hline Group & \multicolumn{3}{|c|}{ Literary section ( $N=443)$} \\
\hline 3-Anxiety test & Correlation value & Signi-ficant & Variance \\
\hline General nxiety & $* * 0.331$ & 0.01 & 0.11 \\
\hline Pre- anxiety test & $* * 0.279$ & $\begin{array}{c}0.01 \\
\text { Low } \cdots\end{array}$ & 0.08 \\
\hline during anxiety test & $* * 0.320$ & 0.01 low & 0.11 \\
\hline 7-Post- anxiety test & $* * 0.288$ & $0.1 \overline{\text { low }}$ & 0.09 \\
\hline Total anxiety & $* * 0.348$ & 0.1 low & 0.13 \\
\hline
\end{tabular}

Table (5) shows that the correlation coefficience is significant at level 0.01 while the significant of the correlation coefficience of all value is low which means that there is no significant correlation coefficience significance between the achievement in English and the whole scores means of the anxiety-test scale of the sample. There is, also, 
no difference between that correlation and the students majors : scientific orliterary.Inquiry (3) asks if there is any statistical significant difference between means of the English test and means of the anxiety - test scale with reference to the educational supervision centers. Table (6) shows the correlation between the English test total scores and the anxiety test scale total scores with reference to the educational supervision centers.

Table (6)

\begin{tabular}{|c|c|c|c|}
\hline Edu.Sup.center & \multicolumn{3}{|c|}{ North $(\mathrm{N}=55)$} \\
\hline $\begin{array}{l}\text { Gen. Rate of anxiety } \\
\text { test dimension }\end{array}$ & Correlation value & Significance & variance \\
\hline 1.general anxiety test & $* * 0.448$ & 0.01 low sig. & 0.20 \\
\hline 2 pre-anxiety test & $* * 0.410$ & 0.01 low sig. & 0.17 \\
\hline During -anxiety test & $* * 0.519$ & 0.01 mid sig. & 0.27 \\
\hline Post- anxiety test & $* * 0.426$ & 0.01 low sig. & 0.18 \\
\hline Total anxiety test & $* * 0.5 ! 5$ & 0.01 & 0.27 \\
\hline Edu.Sup.center & \multicolumn{3}{|c|}{ Sothern west $(\mathrm{N}=303)$} \\
\hline $\begin{array}{l}\text { Gen. Rate of anxiety } \\
\text { test dimension }\end{array}$ & Correlation value & Significance & Variance \\
\hline 1.general anxiety test & $* * 0.4 \overline{36}$ & 0.01 low sig. & 0.20 \\
\hline 2 pre-anxiety test & $* * 0.436$ & 0.01 low sig. & 0.17 \\
\hline During -anxiety test & $* * 0.508$ & $0.01 \mathrm{mid}$ sig. & 0.27 \\
\hline Post- anxiety test & $* * 0.527$ & $0.01 \mathrm{mid}$ sig. & 0.18 \\
\hline Total anxiety test & $* * 0.5 \overline{35}$ & $\begin{array}{c}0.01 \\
\text { Mid sig. }\end{array}$ & 0.27 \\
\hline Edu.Sup.center & \multicolumn{3}{|c|}{ Middle $(\mathrm{N}=\mathbf{8 1})$} \\
\hline $\begin{array}{l}\text { Gen. Rate of anxiety } \\
\text { test dimension }\end{array}$ & Correlation value & Significance & Variance \\
\hline 1.general anxiety test & $* * 0.436$ & $0.01 \mathrm{mid} \mathrm{sig}$ & 0.19 \\
\hline 2 pre-anxiety test & $* * 0.436$ & 0.01 low sig. & 0.19 \\
\hline During -anxiety test & $* * 0.508$ & 0.01 mid sig. & 0.26 \\
\hline Post- anxiety test & $* * 0.527$ & $\begin{array}{c}0.01 \\
\text { Mid sig. }\end{array}$ & 0.28 \\
\hline Total anxiety test & $* * 0.535$ & $\begin{array}{c}0.01 \\
\text { Mod sig. }\end{array}$ & 0.29 \\
\hline
\end{tabular}

The table indicates that there has been no statistical correlation evidence between English test total scores and the anxiety test total scores with reference to the educational 
supervision centers. Some students experience only mild symptoms of test anxiety.

Table (7) displays the correlation between the English test total scores and the anxiety test scale total scores with reference to the educational majors. The table identifies the T-test results of the independent sample for the means of English testscores and the means of the anxiety test scale scores with reference to the educational majors (N-703).

Table (7)

\begin{tabular}{|c|c|c|c|c|c|c|c|c|c|c|}
\hline \multirow{2}{*}{$\begin{array}{l}\text { English exam } \\
\text { and anxiety } \\
\text { test general } \\
\text { scares }\end{array}$} & \multirow{2}{*}{$\begin{array}{c}\text { Educational } \\
\text { majors }\end{array}$} & \multirow[b]{2}{*}{$N$} & \multirow{2}{*}{ Means } & \multirow[b]{2}{*}{$\begin{array}{l}\text { Standard } \\
\text { deviator }\end{array}$} & \multirow{2}{*}{$\begin{array}{l}\text { Percentage } \\
\text { means }\end{array}$} & \multicolumn{2}{|c|}{$\begin{array}{c}\text { Levin test for } \\
\text { variance }\end{array}$} & \multirow{2}{*}{$\begin{array}{l}\text { T-test } \\
\text { Free } \\
\text { Value } \\
701\end{array}$} & \multirow{2}{*}{ siguificance } & \multirow{2}{*}{$\begin{array}{l}\text { Vauiauce } \\
\text { percemtage }\end{array}$} \\
\hline & & & & & & Value & Sig. & & & \\
\hline \multirow[t]{2}{*}{ Euglislu cxan } & Sci. & 260 & +2.29 & 7.937 & 84.6 & \multirow[t]{2}{*}{0.379} & \multirow{2}{*}{$\begin{array}{c}0.538 \\
+* * \\
\text { Not sig. }\end{array}$} & \multirow[b]{2}{*}{1.3 .318} & \multirow[t]{2}{*}{0.901} & \multirow[t]{2}{*}{$\begin{array}{l}8.35 \\
016.7\end{array}$} \\
\hline & Lit. & 443 & 33.94 & 8.473 & 67.9 & & & & & \\
\hline \multirow{2}{*}{$\begin{array}{c}\text { Croberal } \\
\text { anxiety test } \\
\text {. }\end{array}$} & Ssi & 260 & 2.583 & 0,418 & 51.7 & \multirow[t]{2}{*}{0.085} & \multirow{2}{*}{$\begin{array}{c}0.771 \\
* * * \\
\text { Not sig. }\end{array}$} & \multirow[t]{2}{*}{7.161} & & \multirow{2}{*}{$\begin{array}{l}0.236 \\
15.0+07\end{array}$} \\
\hline & Lit & 14.3 & 2.819 & 0.424 & 56.7 & & & & 0.001 & \\
\hline \multirow[t]{2}{*}{$\begin{array}{c}\text { Pre-iusxiety } \\
\text { tast }\end{array}$} & Sci. & 260 & 2.668 & 0.576 & 5.3 .4 & \multirow[t]{2}{*}{7.257} & \multirow[t]{2}{*}{0.01} & \multirow[t]{2}{*}{6.602} & \multirow{2}{*}{0,001} & \\
\hline & Lit. & $4+3$ & 2.982 & 0.662 & $5 \overline{9} .6$ & & & & & $\% \times .5$ \\
\hline \multirow{2}{*}{$\begin{array}{c}\text { Dutriug - } \\
\text { anxiety test }\end{array}$} & Sci. & 260 & 2.599 & 0,622 & 52.0 & \multirow{2}{*}{5.647} & \multirow{2}{*}{0.05} & \multirow{2}{*}{8.373} & \multirow{2}{*}{0.001} & 0.427 \\
\hline & Lit. & 44.3 & 3.026 & 0.701 & 60.5 & & & & & $" / 4.5$ \\
\hline \multirow{2}{*}{$\begin{array}{c}\text { Post-allxiety } \\
\text { test }\end{array}$} & Sci. & 260 & 2.301 & 0.657 & 46.0 & \multirow[t]{2}{*}{16.625} & \multirow[t]{2}{*}{0.001} & \multirow{2}{*}{8.572} & \multirow{2}{*}{0.001} & 0.483 \\
\hline & L.jt. & 443 & 2.784 & 0.815 & 55.7 & & & & & $\left(1 / s^{2}\right), 7$ \\
\hline \multirow{2}{*}{$\begin{array}{c}\text { Total alxiety } \\
\text { test }\end{array}$} & Sei. & 260 & 2.575 & 0.486 & $51: 5$ & & & & & 0.352 \\
\hline & Lit. & $4 \overline{43}$ & 2.227 & 0.552 & 58.5 & & & & & "\%7.0 \\
\hline
\end{tabular}

It can be deduced from the table that the value of Ttest is significant in favour of the scientific group in relation to the English test with $16.7 \%$ more than the literary group, while $\mathrm{T}$-test value is significant for the literary group in relation to the anxiety test scale with $4.7 \%$ more than the scientific group. This means that the scientific major students are low-test anxious than literary major students in doing English test.This might refer to self-confidence instudying English and preparing for the test.The table also states that the T-test value is significant for the literary 
group in relation to the anxiety whole test (before,during and after) with $7.0 \%$ more than the scientific group.

\section{Conclusion}

On surveying English teachers, views about secondary school students' anxiety of test it showshigh test anxiety, nevertheless, the statistical results show some significant correlation between test anxiety scale and English achievement test concerning students' educational majors in favour of literary rather than scientific major. The scores registered for the general anxiety are mild whether before, during or after the achievement test which means that anxiety has a very little effect on the students' performance. This result does not correspond with most earlier mentioned researchers (Sarason - 1984 - Zeidner 1998, Eysnecle -2001, Davis - 2004) who have found that test anxiety decreases attention span, memory and disrupts attention and concentration. The male sample students of the study might have an effect on decreasing test anxiety in so far previous studies cited an increase of test anxiety with female rather than male students. 


\section{References}

1) McDonald, A. S. (2001). The prevalence and effects of test anxiety in school children. Educational Psychology. 21: 89-101.

2) Masson, A.M., Hoyois, P., Pcadot, M., Nahama, V., Petit,F., \&Ansseau, M. (2004). Girls are more successful than boys at the university: Gender group differences in models integrating motivational and aggressive components correlated with testanxiety.[Online]Available:

http://www.ncbi.nlm.nih.gov/sites/entrez?db=journals \&term (August7, 2012).

3) Zeidner, M. (1998). Test-anxiety: The state of the art. New York: Plenum Press.

4). Eysenck, M.W. (2001). Principles of cognitive psychology. Hove, East Sussex: Psychology Press.

5) Keoghi, E., Bond, F.W., French, C.C., Richards, A., \& Davis, R.E. (2004). Test-Anxiety, Susceptibility to destruction and examination performance. Journal of Anxiety, Stress and Coping, 17(3), 241-252.

6) Needham, B.L. (2006). Gender differences in the consequences of depressive symptomatology for educational attainment, social support, and health risk behavior during the transition from adolescence to young adulthood, $\mathrm{PhD}$ thesis, University of Texas.

7) Bailey, K. (1983). Competitiveness and anxiety in adult second language leaning: Looking at and through the diary studies. In H. Seliger and M. Long (Eds.), Classroom-oriented research in second language acquisition (pp. 67-102). Rowley: Mass Newbury House.

8) Horwitz, E., M. Horwitz\& J. Cope. (1986). Foreign language classroom anxiety. Modern Language Journal, 70, 125-32. 
9) MacIntyre, P. D. \& R. C. Gardner. (1994). The subtle effects of language anxiety on cognitive processing in the second language. Language Learning, 44, 283-305.

10) Young, D. J. (1991). Creating a low-anxiety classroom environment: What does language anxiety research suggest? Modern Language Journal, 75, 426-439.

11) Horwitz, E. (1986). Preliminary evidence for the reliability and validity of a foreign language anxiety scale. TESOL Quarterly, 20, 559-564.

12) Mandler, G., \&Sarason, S. B. (1952). A study of anxiety and learning. Journal of Abnormal and Social Psychology, 47, 166-173.

13) Spielberger, C. D. (1980). Test Anxiety Inventory: Preliminary Professional Manual., Palo Alto, CA: Consulting Psychological Press.

14) Spielberger, C.D. (1980). Preliminary Professional Manual for the Test Anxiety Inventory: TAI.Counseling Psychologists Press, New York.

15) Pintrich, P. R., \&Schunk, D. (2002). Motivation in education: Theory, research and applications (2nd ed.). Upper Saddle River, NJ: Merrill Prentice Hall.

16) Chowdhury, A., \&Pati, C. (1997). Effect of Selected Family Variables on Social Preference, AcademicAchievement and Self-Concept of Elementary School Children, Early Child Development and Care, 137: 1, 133-143

17) Fouladi, M. (2007). Academic achievement. Journal of DidrareAshena(Meet familiar), No, 28. [Online] Available: http://noorportal.net/473-1-noor.aspx.

18) Peelo, M., \& Wareham, T. (2002). Failing students in higher education. Philadelphia: Sreh and Open University Press. 
19) Sena, W. J., Lowe, P. \& Lee, S. W. (2007). Significant predictors of test anxiety among students with and without learning disabilities. Journal of Learning Disprfers, 40(4), 360-376.

20) Cassady, J. C., \& Johnson, R. E. (2002). Cognitive Test Anxiety and Academic Performance. Contemporary Educa-tional Psychology, 27(2), 270-295. doi:10.1006/ceps. 2001.1094, available online at http: //www.idealibrary.com on

21) Rezazadeh, M., \&Tavakoli, M. (2009). Investigating - the Relationship among Test Anxiety, Gender, Academic Achievement and Years of Study: A Case of Iranian. EFL University Students. English Language Teaching, 2(4).

22) Wine, J. D. (1978). Test anxiety and evaluation threat: Children's behavior in the classroom. Journal of Abnormal Child Psychology, 7(1), 45-59.

23) Hembree, R. (1988). Correlates, causes and treatment of test anxiety. Review of Educational Research, 58, 47-77.

24) Eman, S., \&Farooqi, N.Y. (2005). Gender differences in test anxiety and level of examination stress among master's students. Unpublished Master Thesis Department of Applied Psychology, University of the Punjab, Lahore, Pakistan.

25) Keeves, J., 1985. Sex differences in ability and achievement. The International Encyclopedia of Educational Research and Studies. Oxford: Pergamon Press.

26) Zoller, L. and Bencham, D., 1990. Gender differences in exam type, preferences, test anxiety and academic achievement in college science education. New York:John Wiley and Sons. 
27) Chapell, M. S.; Blanding, Z. B.; Silvestein, M.E.; Takahashi, M. N. B.; Newman, B. Gubi, A. and McCain, N., 2005. Test anxiety and academic performance in undergraduateand graduate students. Journal of Educational psychology, 97 (2): 268-274.

28) Soffer, M. E., 2008. Elementary students' test anxiety in relation to the Florida Comprehensive Assessment Test (FCAT). Retrieved August16, 2012 fromhttp://etd.lib.fsu.edu/theses/available/etd06092008-111004/ unrestricted/SofferMThesis.pdf 


\section{Appendix :1}

Items of the test-anxiety scale

\begin{tabular}{|l|l|}
\hline $1-$ & $\begin{array}{l}\text { Achieving good scores at any English exam, increases } \\
\text { my self confidence in the following exam. }\end{array}$ \\
\hline $2-$ & $\begin{array}{l}\text { I feel confidence and confortable when I am going to } \\
\text { perform an English exam. }\end{array}$ \\
\hline $3-$ & $\begin{array}{l}\text { When I finish English exams, I feel that I could answer } \\
\text { better than'Idid. }\end{array}$ \\
\hline $4-$ & Time of English exams should not be time of fear. \\
\hline $5-$ & $\begin{array}{l}\text { Influential people of educational authority should be } \\
\text { aware of some students ' nervous when addressing } \\
\text { English exams that affects their performances. }\end{array}$ \\
\hline $6-$ & $\begin{array}{l}\text { During English exams I suspect if I would be able to } \\
\text { pursue my university education. }\end{array}$ \\
\hline $7-$ & $\begin{array}{l}\text { During English exams I feel that my heart's strokes } \\
\text { increase. }\end{array}$ \\
\hline $8-$ & $\begin{array}{l}\text { I will be worried when 1 know that there is a sudden } \\
\text { English exam. }\end{array}$ \\
\hline $9-$ & $\begin{array}{l}\text { I don't see any reason behind students irritation from } \\
\text { English exam. }\end{array}$ \\
\hline $10-$ & $\begin{array}{l}\text { I can answer better at English exams if there is no } \\
\text { pressure exits due to limitation of exam-time. }\end{array}$ \\
\hline $11-$ & I feel worried before undertaking English exams. \\
\hline $12-$ & $\begin{array}{l}\text { I feel fear and uncomforting before undertaking final } \\
\text { English exams. }\end{array}$ \\
\hline $13-$ & $\begin{array}{l}\text { I am thinking, all the times, about the scores that I obtain } \\
\text { at English syllabus because it has an effect on studying } \\
\text { and performing English exams. }\end{array}$ \\
\hline $14-$ & I suffer gloomy after English exams. \\
\hline $15-$ & $\begin{array}{l}\text { Feeling depress about English exams' results influences } \\
\text { my performance on the exam itself. }\end{array}$ \\
\hline $16-$ & $\begin{array}{l}\text { I am so upset about English exams even if I were ready } \\
\text { to do them. }\end{array}$ \\
\hline
\end{tabular}




\begin{tabular}{|l|l|}
\hline $17-$ & $\begin{array}{l}\text { I believe that all students in English exams are better } \\
\text { than me }\end{array}$ \\
\hline $18-$ & $\begin{array}{l}\text { I try to getredof anxiety after English exams despite my } \\
\text { readiness to them }\end{array}$ \\
\hline $19-$ & $\begin{array}{l}\text { This statement is coming to my mind when I do my } \\
\text { English exam :' if I didn't know the answer why then I } \\
\text { would be worried. }\end{array}$ \\
\hline $20-$ & $\begin{array}{l}\text { I prefer to write a report or do a research than I perform } \\
\text { an English exam to get full scores. }\end{array}$ \\
\hline 21 & $\begin{array}{l}\text { I work hard to be ready for English exams more than I } \\
\text { did when I studied the English syllabus. }\end{array}$ \\
\hline 22 & I didn't taste food before the time of English exams. \\
\hline 23 & $\begin{array}{l}\text { I need to revise all English syllabus contents rapidly } \\
\text { before English exams. }\end{array}$ \\
\hline 24 & I feel tremble of my bones before English exams. \\
\hline 25 & I concentrate my thinking on failure at English exams. \\
\hline 26 & $\begin{array}{l}\text { I don't feel comfortable before the end of English } \\
\text { exams. }\end{array}$ \\
\hline 27 & $\begin{array}{l}\text { I feel severe cool in my body at the time of English } \\
\text { exams. }\end{array}$ \\
\hline 28 & $\begin{array}{l}\text { My excitements and emotions don't affect performing } \\
\text { English exams. }\end{array}$ \\
\hline 29 & $\begin{array}{l}\text { I consider things, during English exams which are not } \\
\text { related to English syllabus. }\end{array}$ \\
\hline 30 & I sweat during English exams. \\
\hline 31 & $\begin{array}{l}\text { I feel that what I did was bad at English exams although } \\
\text { I fully prepared for it. }\end{array}$ \\
\hline 32 & I hope that English exams don't depress me. \\
\hline 33 & $\begin{array}{l}\text { I feel worry during English exam in so far I forget all } \\
\text { facts and information I knew. }\end{array}$ \\
\hline 34 & $\begin{array}{l}\text { I feel vomiting after English exams as a result of its } \\
\text { irritation. }\end{array}$ \\
\hline 35 & $\begin{array}{l}\text { I think I will learn English better if English exams are } \\
\text { dropped }\end{array}$ \\
\hline
\end{tabular}




\begin{tabular}{|l|l|}
\hline 36 & I feel anxiety while performing English exams. \\
\hline 37 & I feel headache before English exams. \\
\hline 38 & $\begin{array}{l}\text { I find difficulty when I eat and digest in the day } \\
\text { morning of English exams. }\end{array}$ \\
\hline 39 & I feel dry my throat when I do English exams. \\
\hline 40 & $\begin{array}{l}\text { I feel irritation when teachers and invigilators entering } \\
\text { English exams' room. }\end{array}$ \\
\hline 41 & $\begin{array}{l}\text { Instructions of teachers and invigilators disturb me } \\
\text { during English exams. }\end{array}$ \\
\hline 42 & $\begin{array}{l}\text { I feel lack of self-confidence during answering questions } \\
\text { of English exams. }\end{array}$ \\
\hline
\end{tabular}




\section{Appendix II}

Test - anxiety items for Domains

\begin{tabular}{|c|c|c|c|}
\hline Domain (1) & Domain (2) & Domain (3) & Domain (4) \\
\hline $\begin{array}{ll}\text { Anxiety } & \text { test } \\
\text { general items }\end{array}$ & $\begin{array}{l}\text { Pre-anxiety test } \\
\text { items }\end{array}$ & $\begin{array}{l}\text { During- } \\
\text { anxiety test } \\
\text { items }\end{array}$ & $\begin{array}{l}\text { Post-anxiety } \\
\text { test items }\end{array}$ \\
\hline $\begin{array}{l}\text { 1- Achieving } \\
\text { good scores at any } \\
\text { English exam } \\
\text { increases my self- } \\
\text { confidence in the } \\
\text { following exams. }\end{array}$ & $\begin{array}{l}\text { 1- I will be } \\
\text { worried when I } \\
\text { knew that there } \\
\text { is a sudden } \\
\text { English exams. }\end{array}$ & $\begin{array}{l}\text { 1- I argue } \\
\text { during English } \\
\text { exams if I } \\
\text { were able to } \\
\text { pursue my } \\
\text { university } \\
\text { education }\end{array}$ & $\begin{array}{l}\text { 1 when I } \\
\text { finish English } \\
\text { exams, I feel } \\
\text { that I could } \\
\text { answer better } \\
\text { than I did. }\end{array}$ \\
\hline $\begin{array}{l}2-\text { I Feel } \\
\text { confidence and } \\
\text { comforting when I } \\
\text { knew I am going } \\
\text { to perform an } \\
\text { English exam. }\end{array}$ & $\begin{array}{l}\text { 2-I feel worried } \\
\text { before } \\
\text { undertaking } \\
\text { English } \\
\text { exams. }\end{array}$ & $\begin{array}{l}\text { 2-During } \\
\text { English exams } \\
\text { I feel my } \\
\text { heart's strokes } \\
\text { increase }\end{array}$ & $\begin{array}{lr}2 \quad \text { I } & \text { suffer } \\
\text { gloomy } & \text { after } \\
\text { English } & \\
\text { exams } & \end{array}$ \\
\hline $\begin{array}{l}\text { 3-When I finish } \\
\text { English exams, I } \\
\text { feel that I could } \\
\text { answer better than } \\
\text { I did. }\end{array}$ & $\begin{array}{l}\text { 3- I Feel fear and } \\
\text { uncomfortable } \\
\text { before } \\
\text { undertaking final } \\
\text { English exam }\end{array}$ & $\begin{array}{l}3-1 \text { Assume } \\
\text { that all } \\
\text { students at } \\
\text { English exains } \\
\text { are better than } \\
\text { me }\end{array}$ & $\begin{array}{l}3 \text { I try to get } \\
\text { red of anxiety } \\
\text { after English } \\
\text { exams despite } \\
\text { my readiness } \\
\text { to it. }\end{array}$ \\
\hline $\begin{array}{l}\text { 4-Time of English } \\
\text { exams should not } \\
\text { be time of fear. }\end{array}$ & $\begin{array}{l}4 \text { Feeling } \\
\text { depressed } \\
\text { about English } \\
\text { exam results } \\
\text { influences my } \\
\text { performances } \\
\text { on the exams } \\
\text { themselves }\end{array}$ & $\begin{array}{l}\text { 4-This } \\
\text { statement is } \\
\text { coming to my } \\
\text { mind when I do } \\
\text { my English } \\
\text { exams "if I } \\
\text { didn't know the } \\
\text { answer why } \\
\text { then I would be } \\
\text { worried }\end{array}$ & $\begin{array}{l}\text { 4- I feel that } \\
\text { what I did } \\
\text { was bad at } \\
\text { English } \\
\text { exams } \\
\text { although I } \\
\text { fully prepared } \\
\text { it }\end{array}$ \\
\hline
\end{tabular}




\begin{tabular}{|c|c|c|c|}
\hline Domain (1) & Domain (2) & Domain (3) & Domain (4) \\
\hline $\begin{array}{l}\text { 3- Influential } \\
\text { people of } \\
\text { educational } \\
\text { authority should } \\
\text { be aware of some } \\
\text { students' nervous } \\
\text { when addressing } \\
\text { English exams } \\
\text { that affects their } \\
\text { performances. }\end{array}$ & $\begin{array}{l}\text { 5- I am so } \\
\text { worried about } \\
\text { the English } \\
\text { exams even if I } \\
\text { am ready to do } \\
\text { them }\end{array}$ & $\begin{array}{l}5 \text { - I } \\
\text { concentrate } \\
\text { thinking on } \\
\text { failure at } \\
\text { English } \\
\text { syllabus } \\
\text { during the } \\
\text { time of } \\
\text { English exams }\end{array}$ & $\begin{array}{l}5 \quad \text { I feel } \\
\text { vomiting after } \\
\text { English } \\
\text { exams as a } \\
\text { result of its } \\
\text { irritation. }\end{array}$ \\
\hline $\begin{array}{l}\text { 6-I can answer better } \\
\text { at English exams if } \\
\text { there is no pressure } \\
\text { put on me by test } \\
\text { limited time. }\end{array}$ & $\begin{array}{l}6-\text { I work hard to } \\
\text { be ready for } \\
\text { English exams } \\
\text { more than I did } \\
\text { when I studied } \\
\text { English syllabus }\end{array}$ & $\begin{array}{l}\text { 6- I don't feel } \\
\text { comfortable } \\
\text { before English } \\
\text { exams times } \\
\text { up }\end{array}$ & \\
\hline $\begin{array}{l}\text { 7- I am thinking, } \\
\text { all the times, } \\
\text { about the scores } \\
\text { that I obtain at } \\
\text { English syllabus, } \\
\text { because it has an } \\
\text { effect on studying } \\
\text { and performing } \\
\text { English exams. }\end{array}$ & $\begin{array}{l}\text { 7- I don't taste } \\
\text { food before the } \\
\text { time of English } \\
\text { exams }\end{array}$ & $\begin{array}{l}7 \text {-I feel sever } \\
\text { body-cool at } \\
\text { the time of } \\
\text { English exams }\end{array}$ & \\
\hline $\begin{array}{l}8-1 \text { prefer to write a } \\
\text { report or do a } \\
\text { research than I } \\
\text { perform an English } \\
\text { exam to get full } \\
\text { scores. }\end{array}$ & $\begin{array}{l}\text { 8- I feel to revise } \\
\text { all English } \\
\text { syllabus contents } \\
\text { rapidly before } \\
\text { English exams. }\end{array}$ & $\begin{array}{l}8- \\
\text { excitements and } \\
\text { emotions don't } \\
\text { affect performing } \\
\text { English exams. }\end{array}$ & \\
\hline $\begin{array}{l}\text { 9-I hope that } \\
\text { English exams } \\
\text { don't depress me. }\end{array}$ & $\begin{array}{l}\text { 9- I feel } \\
\text { tremble of my } \\
\text { bones before } \\
\text { English exams }\end{array}$ & $\begin{array}{l}9-\quad \text { I consider } \\
\text { things during } \\
\text { English exams } \\
\text { which aren't } \\
\text { related to English } \\
\text { syllabus. }\end{array}$ & \\
\hline
\end{tabular}




\begin{tabular}{|c|c|c|c|}
\hline Domain (1) & Domain (2) & Domain (3) & Domain (4) \\
\hline \multirow[t]{6}{*}{$\begin{array}{l}10-\mathrm{I} \text { feel irritation } \\
\text { when teachers and } \\
\text { invigilators entering } \\
\text { English } \\
\text { rooms. }\end{array}$} & $\begin{array}{l}10-\quad \text { I feel } \\
\text { headache } \\
\text { before exams }\end{array}$ & $\begin{array}{l}10 \quad-\quad I \\
\text { sweat during } \\
\text { English exam }\end{array}$ & \\
\hline & $\begin{array}{l}\text { 11- I find } \\
\text { difficulty when } \\
\text { I eat and digest } \\
\text { in the morning } \\
\text { day of English } \\
\text { exams. }\end{array}$ & $\begin{array}{l}11-\text { I feel } \\
\text { worry during } \\
\text { English exam } \\
\text { in so far I } \\
\text { forget. }\end{array}$ & \\
\hline & $\begin{array}{l}12 \text { I feel } \\
\text { irritation when } \\
\text { and teachers and } \\
\text { invigilators } \\
\text { entering English } \\
\text { exams rooms }\end{array}$ & $\begin{array}{l}12-\quad \text { I feel } \\
\text { anxiety while } \\
\text { performing } \\
\text { English exam }\end{array}$ & r \\
\hline & & $\begin{array}{l}\text { 13- I feel dry } \\
\text { in my throat } \\
\text { when I do } \\
\text { English exam. }\end{array}$ & \\
\hline & & $\begin{array}{l}\text { 14-Instructions } \\
\text { of teachers and } \\
\text { invigilators } \\
\text { disturb me } \\
\text { during English } \\
\text { exam. }\end{array}$ & \\
\hline & & $\begin{array}{l}\text { 15- I feel lack } \\
\text { of self- } \\
\text { confidence } \\
\text { during } \\
\text { answering } \\
\text { questions of } \\
\text { English } \\
\text { exams. }\end{array}$ & \\
\hline
\end{tabular}




\section{Appendix : III}

Test - anxiety scale

\begin{tabular}{|c|c|c|c|c|c|c|}
\hline No. & Items & $\begin{array}{c}\text { Strongly } \\
\text { agree }\end{array}$ & Agree & $\begin{array}{l}\text { Agree } \\
\text { to } \\
\text { some } \\
\text { extent }\end{array}$ & Disagree & $\begin{array}{l}\text { Strongly } \\
\text { disagre }\end{array}$ \\
\hline 1 & $\begin{array}{l}\text { Achieving good } \\
\text { scores at any } \\
\text { English exam } \\
\text { increases my } \\
\text { self-confidence } \\
\text { in the following } \\
\text { exam. }\end{array}$ & & & & & \\
\hline 2 & $\begin{array}{l}\text { I feel confidence } \\
\text { and comfortable } \\
\text { when I knew I } \\
\text { am going to } \\
\text { perform an } \\
\text { English exams. }\end{array}$ & & & & & \\
\hline 3 & $\begin{array}{l}\text { When I finish } \\
\text { English exams, I } \\
\text { feel that I could } \\
\text { answer better } \\
\text { than I did. }\end{array}$ & & & & & \\
\hline 4 & $\begin{array}{l}\text { Time of English } \\
\text { exams shouldn't } \\
\text { be time of fear. }\end{array}$ & & & & & \\
\hline 5 & $\begin{array}{l}\text { Influential } \\
\text { people of } \\
\text { educational } \\
\text { authority should } \\
\text { be aware of } \\
\text { some students' } \\
\text { nervous when } \\
\text { addressing } \\
\text { English exams } \\
\text { that affects their } \\
\text { performances. }\end{array}$ & & & & & \\
\hline
\end{tabular}




\begin{tabular}{|c|c|c|c|c|c|c|}
\hline No. & Items & $\begin{array}{c}\text { Strongly } \\
\text { agree }\end{array}$ & Agree & $\begin{array}{l}\text { Agree } \\
\text { to } \\
\text { some } \\
\text { extent }\end{array}$ & Disagree & $\begin{array}{l}\text { Strongly } \\
\text { disagree }\end{array}$ \\
\hline 6 & $\begin{array}{l}\text { During English } \\
\text { exams, I suspect } \\
\text { if I would be } \\
\text { able to pursue } \\
\text { my university } \\
\text { education. }\end{array}$ & & & & & \\
\hline 7 & $\begin{array}{l}\text { During English } \\
\text { exams, I feel that } \\
\text { my heart's } \\
\text { strokes increase }\end{array}$ & & & & & \\
\hline 8 & $\begin{array}{l}\text { I will be worried } \\
\text { when l knew } \\
\text { that there is a } \\
\text { sudden English } \\
\text { exams }\end{array}$ & & & & & \\
\hline 9 & $\begin{array}{l}\text { I don't see any } \\
\text { reason behind } \\
\text { students' } \\
\text { irritation from } \\
\text { English exams }\end{array}$ & & & & & \\
\hline . & $\begin{array}{l}\text { I can answer } \\
\text { better at English } \\
\text { exams if there } \\
\text { were no pressure } \\
\text { exists due to } \\
\text { limitation of } \\
\text { exams' time. }\end{array}$ & & & & & \\
\hline 11 & $\begin{array}{l}\text { I feel worried } \\
\text { before } \\
\text { undertaking } \\
\text { English exams }\end{array}$ & & & & & \\
\hline 12 & $\begin{array}{l}\text { I feel fear and } \\
\text { uncomfortable } \\
\text { before } \\
\text { undertaking final } \\
\text { English exams. }\end{array}$ & & & & & \\
\hline
\end{tabular}




\begin{tabular}{|c|c|c|c|c|c|c|}
\hline No. & Items & $\begin{array}{c}\text { Strongly } \\
\text { agree }\end{array}$ & Agree & $\begin{array}{l}\text { Agree } \\
\text { to } \\
\text { some } \\
\text { extent }\end{array}$ & Disagree & $\begin{array}{l}\text { Strongly } \\
\text { disagree }\end{array}$ \\
\hline 13 & $\begin{array}{l}\text { All the times I } \\
\text { am thinking } \\
\text { about the scores } \\
\text { that I obtain at } \\
\text { English syllabus } \\
\text { because it has an } \\
\text { effect on } \\
\text { studying and } \\
\text { performance of } \\
\text { English exams. }\end{array}$ & & & & & \\
\hline 14 & $\begin{array}{l}\text { I suffer gloomy } \\
\text { after English } \\
\text { exams. }\end{array}$ & & & & & \\
\hline 15 & $\begin{array}{l}\text { Feeling } \\
\text { depressed about } \\
\text { English exams' } \\
\text { results } \\
\text { influences my } \\
\text { performance on } \\
\text { the exam itself. }\end{array}$ & & & & & \\
\hline 16 & $\begin{array}{l}\text { I'm so upset } \\
\text { about English } \\
\text { exams even if I } \\
\text { am ready to do } \\
\text { them }\end{array}$ & & & & & \\
\hline 17 & $\begin{array}{l}\text { assume that all } \\
\text { students at } \\
\text { English exams } \\
\text { are better than } \\
\text { me }\end{array}$ & & & & & \\
\hline 18 & $\begin{array}{l}\text { I try to get red of } \\
\text { anxiety after } \\
\text { English exams } \\
\text { despite my } \\
\text { readiness to do it }\end{array}$ & & & & & \\
\hline
\end{tabular}


is:

\begin{tabular}{|c|c|c|c|c|c|c|}
\hline No. & Items & $\begin{array}{l}\text { Strongly } \\
\text { agree }\end{array}$ & Agree & $\begin{array}{l}\text { Agree } \\
\text { to } \\
\text { some } \\
\text { extent } \\
\end{array}$ & Disagree & $\begin{array}{l}\text { Strongly } \\
\text { disagree }\end{array}$ \\
\hline 19 & $\begin{array}{l}\text { The statement } \\
\text { coming to my } \\
\text { mind when I do } \\
\text { my English } \\
\text { exams is: "if I } \\
\text { didn't know the } \\
\text { answer why then } \\
\text { I would be } \\
\text { worried. }\end{array}$ & & & & & \\
\hline 20 & $\begin{array}{l}\text { I prefer to write } \\
\text { a report or do a } \\
\text { research than I } \\
\text { perform an } \\
\text { English exam } \\
\text { and get full } \\
\text { scores. }\end{array}$ & & & & & \\
\hline 21 & $\begin{array}{l}\text { I work hard to be } \\
\text { ready for } \\
\text { English exams } \\
\text { more than I did } \\
\text { when I studied } \\
\text { the English } \\
\text { syllabus }\end{array}$ & - & & & & \\
\hline 22 & $\begin{array}{l}\text { I don't taste food } \\
\text { before the time } \\
\text { of English } \\
\text { exams. }\end{array}$ & & & & & \\
\hline 23 & $\begin{array}{l}\text { I need to revise } \\
\text { all English } \\
\text { syllabus contents } \\
\text { rapidly before } \\
\text { English exams. }\end{array}$ & & & & & \\
\hline 24 & $\begin{array}{l}\text { I feel tremble of } \\
\text { my bones before } \\
\text { exams. }\end{array}$ & & & & & \\
\hline
\end{tabular}




\begin{tabular}{|c|c|c|c|c|c|c|}
\hline No. & Items $\quad \therefore$ & $\begin{array}{l}\text { Strongly } \\
\text { agree }\end{array}$ & Agree & $\begin{array}{l}\text { Agree } \\
\text { to } \\
\text { some } \\
\text { extent }\end{array}$ & Disagree & $\begin{array}{l}\text { Strongly } \\
\text { disagree }\end{array}$ \\
\hline$\because$ & $\begin{array}{l}\text { I concentrate my } \\
\text { thinking on } \\
\text { failure at English } \\
\text { exams }\end{array}$ & & & & & \\
\hline 26 & $\begin{array}{l}\text { I don't feel } \\
\text { comfortable } \\
\text { before the end of } \\
\text { English exams. }\end{array}$ & & & & & \\
\hline 27 & $\begin{array}{l}\text { I feel severe cool } \\
\text { in my body at } \\
\text { the time of } \\
\text { English exams. }\end{array}$ & & & & & \\
\hline 28 & $\begin{array}{l}\text { My excitements } \\
\text { and emotions } \\
\text { don't affect } \\
\text { performing } \\
\text { English exams. }\end{array}$ & & & & & \\
\hline 29 & $\begin{array}{l}\text { I consider things } \\
\text { during English } \\
\text { exams which are } \\
\text { not related to } \\
\text { English syllabus. }\end{array}$ & & & & & \\
\hline 30 & $\begin{array}{l}\text { I sweat during } \\
\text { English exams. }\end{array}$ & & & & & \\
\hline 31 & $\begin{array}{l}\text { I feel that what I } \\
\text { did was bad at } \\
\text { English exams } \\
\text { although I fully } \\
\text { prepared for it. }\end{array}$ & & & & & \\
\hline 32 & $\begin{array}{l}\text { I hope that } \\
\text { English exams } \\
\text { don't depress } \\
\text { me. }\end{array}$ & & & & & \\
\hline
\end{tabular}




\begin{tabular}{|c|c|c|c|c|c|c|}
\hline No. & Items & $\begin{array}{c}\text { Strongly } \\
\text { agree }\end{array}$ & Agree & $\begin{array}{l}\text { Agree } \\
\text { to } \\
\text { some } \\
\text { extent }\end{array}$ & Disagree & $\begin{array}{l}\text { Strongly } \\
\text { disagree }\end{array}$ \\
\hline 33 & $\begin{array}{l}\text { I feel worry } \\
\text { during English } \\
\text { exam in so far I } \\
\text { forget facts and } \\
\text { information I } \\
\text { knew. }\end{array}$ & & & & & \\
\hline 34 & $\begin{array}{l}\text { I feel vomiting } \\
\text { after English } \\
\text { exams as a result } \\
\text { of its irritation. }\end{array}$ & & & & & \\
\hline 35 & $\begin{array}{l}\text { I think I will } \\
\text { learn English } \\
\text { better if English } \\
\text { exams are } \\
\text { adapted. }\end{array}$ & $\cdot$ & & & & \\
\hline 36 & $\begin{array}{l}\text { I feel anxiety } \\
\text { while } \\
\text { performing } \\
\text { English exams }\end{array}$ & & & & & \\
\hline $3 \overline{7}$ & $\begin{array}{l}\text { I feel headache } \\
\text { before English } \\
\text { exams. }\end{array}$ & & & & & \\
\hline 38 & $\begin{array}{l}\text { I find difficulty } \\
\text { when I eat and } \\
\text { digest in the } \\
\text { morning of } \\
\text { English exams. }\end{array}$ & & & & & \\
\hline 39 & $\begin{array}{l}\text { I feel dry in my } \\
\text { throat when I do } \\
\text { English exams. }\end{array}$ & & & & & \\
\hline 40 & $\begin{array}{l}\text { I feel irritation } \\
\text { when teachers } \\
\text { and investigators } \\
\text { entering English } \\
\text { exams. }\end{array}$ & & & & & \\
\hline
\end{tabular}




\begin{tabular}{|l|l|l|l|l|l|l|}
\hline No. & \multicolumn{1}{|c|}{ Items } & $\begin{array}{c}\text { Strongly } \\
\text { agree } \\
41\end{array}$ & Agree & $\begin{array}{c}\text { Agree } \\
\text { to } \\
\text { some } \\
\text { extent }\end{array}$ & Disagree & $\begin{array}{c}\text { Strongly } \\
\text { disagree }\end{array}$ \\
\hline 42 & $\begin{array}{l}\text { Instructions of } \\
\text { teacher and } \\
\text { invigilators } \\
\text { disturb me } \\
\text { during English } \\
\text { exams. }\end{array}$ & $\begin{array}{l}\text { I feel lack of } \\
\text { self- confidence } \\
\text { during } \\
\text { answering } \\
\text { questions of } \\
\text { English exams. }\end{array}$ & & & & \\
\hline
\end{tabular}




\section{Appendix : IV}

Items of the test-anxiety scale (Arabic version)

1

$$
\text { بنفسي يٌْالاختبار التالي. }
$$

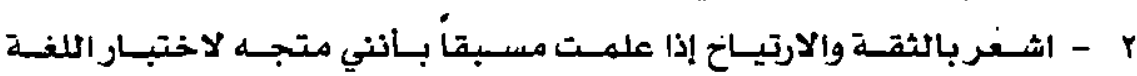

$$
\text { الإنجليزية. }
$$

r - م أشعر بعد الانتهـاء مـن اختبـار اللغـة الإنجليزيـة أنه كـان يمكن أن أجيـب على الاسئلة بشكل أفضل مما قمت به فعلاً.

؛ - يجب أن لا تكون فترات اختبارات اللفة الإنجليزية فترات توتر.

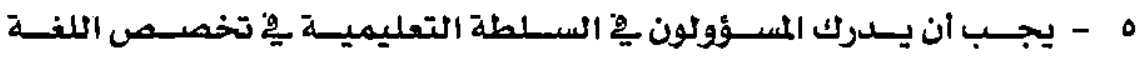
الإنجليزية عصبية بعض الطلاب فِّ بعض اختبارات اللنـة الإنجليزيـة ممـا

$$
\text { يؤثر على اداثهه. }
$$

1

$$
\text { الجامعية. }
$$

V - أشعر ان ضريات قلبي تتزايد أثناء اختبارات اللفة الإنجليزية.

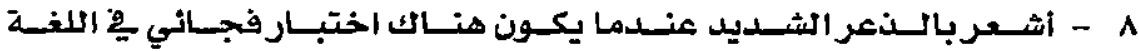

\section{الإنجليزية.}

9 - لا أرى أي سبب عندما ينزعج بعض الطلاب من اختبارات اللفة الإنجليزية.

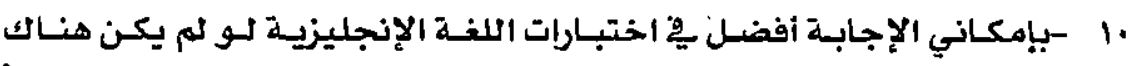

$$
\text { ضغط بسبب التقيد بزمن معين. }
$$

11 - أشعر بالقلق قَبل أداثي اختبارات اللغة الإنجليزية. ir - ir

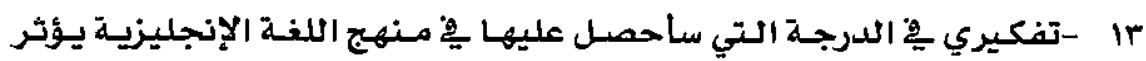

$$
\text { على دراستي وأداثي وِّ اختبار اللغة الإنجليزية. }
$$

18 أصاب بالاكتئاب بعد انتهاء اختبار اللغة الإنجليزية. 10 - 10 - 


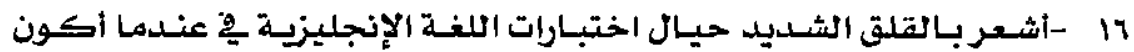

مستعدأ لها.

IV - IV 1 أحاول التخلص من القلق بعل انتهـاء اختبـار اللغـة الإنجليزيـة على الرغم من تحضيري الجيد لله.

19 - 19 الإجابة الآن فلماذا أقلقى).

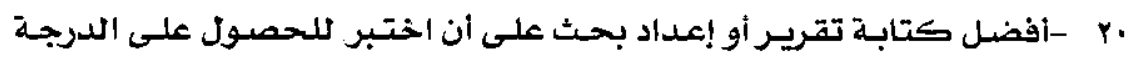

$$
\text { (ممتاز) مِّ مقرر اللغة الإنجليزية. }
$$

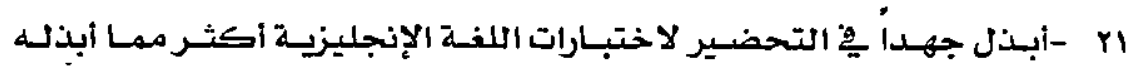
لاستذكار المقرد

YY - Y استمتع بالطعام قبل اختبارات اللغة الإنجليزية

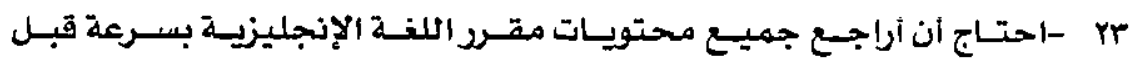
الاختبار.

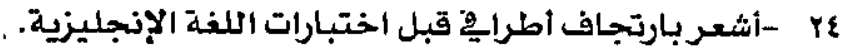

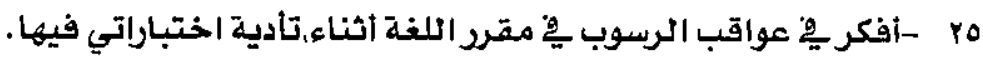
r r - آشعر بعدم الارتياح قبيل انتهاء اختبار اللغة الإنجليزية. - FV

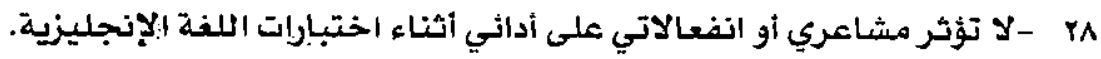

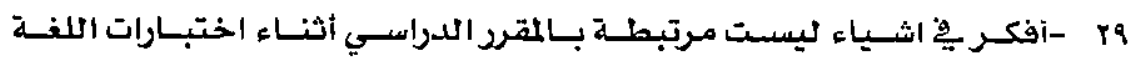
الإنجليزية.

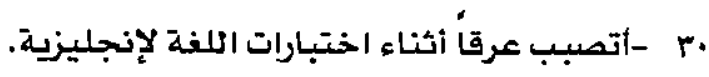

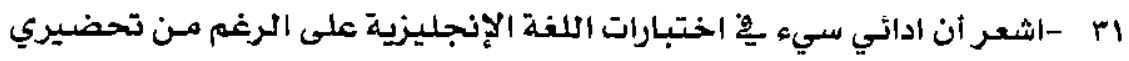
الجيد نها.

r - أتمنى أن لا تزعجني اختبارات اللغة الإنجليزية. 


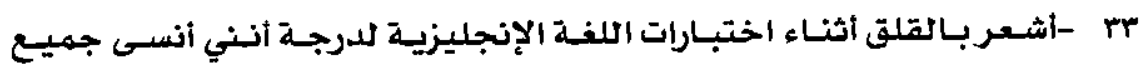

$$
\text { الحقائق والمعلومات التي أعرفها. }
$$

\&r أشعر بالغثيان بعد اختبارات اللغة الإنجليزية نتيجة التوتر الشديد.

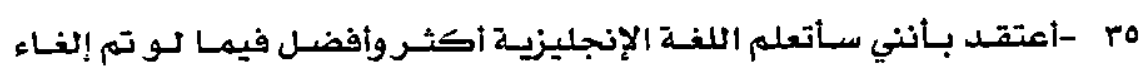

$$
\text { اختبارات اللغة الإنجليزية. }
$$

דr -أشعر بالقلق الشديد أثناء تأدية اختبارات اللغة الإنجليزية.

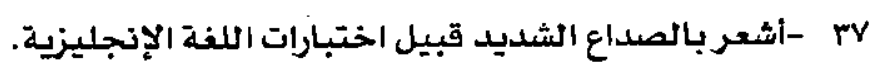

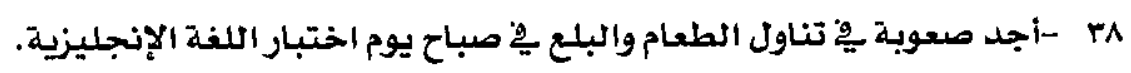

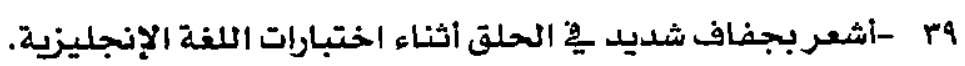
•أشعر بالتوتر عند دخول الأساتذة والمراقبين قاعة الاختبار. اع -يزعجني تعليمات الأستاذ والمراقب أثناء اختبار اللنة الإنجليزية.

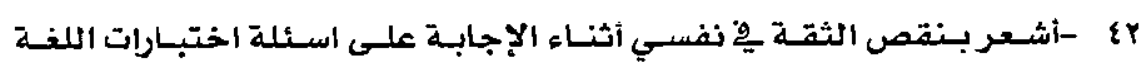
الإنجليزية. 